\title{
Perbandingan Karakteristik Inflasi Kota-Kota Di Indonesia Bagian Timur Sebelum Dan Sesudah Krisis Moneter 1998
}

\author{
Adi Setiawan \\ Program Studi Matematika, Fakultas Sains dan Matematika \\ Univers itas Kristen Satya Wacana, J1. Diponegoro 52-60 Sa latiga 50711 \\ Email : adi_setia_03@yahoo.com
}

\begin{abstract}
Abstrak
Dalam makalah ini dipresentasikan karakteristik inflasi kota-kota di Indonesia bagian Timur yang sudah digunakan dalam perhitungan inflasi bulanan mulai tahun 1979 yaitu Manado, Ambon, Makasar, Jayapura, Makasar, Denpasar, Kupang dan Mataram. Karakteristik tersebut dipisahkan antara waktu sebelum dan sesudah krisis moneter 1998. Inflasi tahunan untuk kota-kota tersebut cenderung mempunyai pola yang sama setelah krisis moneter namun sebelum krisis moneter kota Ambon mempunyai pola yang cenderung berbeda dengan yang lainnya. Rata-rata inflasi bulanan dan rata-rata inflasi tahunan cenderung turun secara signifikan sesudah krisis moneter dibandingkan sebelum krisis moneter.
\end{abstract}

Kata kunci : karakteristik inflasi, statistik deskriptif, krisis moneter.

\begin{abstract}
In this paper it is presented the inflation characteristics of cities in eastern Indonesia that has been used in the calculation of the monthly inflation started in 1979, namely Manado, Ambon, Makassar, Jayapura, Makas sar, Denpasar, Kupang and Mataram. These characteristics are separated between the time before and after the financial crisis of 1998. Annual inflation of those cities tend to have the same pattern after the financial crisis in 1998 but before the financial crisis, Ambon city tends to have a pattern that is different from the others. Average monthly inflation and the average of annual inflation rate tends to drop significantly after the financial crisis than before.
\end{abstract}

Keywords: characteristics of inflation, descriptive statistics, monetary crisis.

\section{Pendahuluan}

Krisis moneter 1998 (selanjutnya dinamakan kris is moneter saja) sangat berpengaruh terhadap inflasi bulanan di Indonesia. Pada saat itu, Indonesia mengalami inflasi sebesar 77,67 \% dan inflasi bulanan terbesar terjadi pada bulan Februari 1998 yaitu sebesar 12,76 \%. Inflasi bulanan itu jauh lebih besar dibandingkan dengan inflasi bulanan yang terjadi pada bulan Juli 2013 yaitu sebesar $3,29 \%$ akibat kenaikan harga BBM tanggal 22 Juni 2013 lalu dan bahkan lebih besar dari inflasi tahun $2013(8,38 \%)$. Inflasi itu bila dibandingkan dengan keadaan inflasi tahun-tahun sebelum krisis moneter mempunyai rata-rata sebesar 9,34\% (dari tahun 1979 sampai dengan tahun 1997). Setelah kris is moneter, inflasi tahunan mempunyai rata-rata sebesar 7,53\%.

Statistik deskriptif dapat digunakan untuk menjelaskan karakteristik inflasi bulanan (e.g. Setiawan, 2012a dan Setiawan, 2012b). Karakteristik inflasi bulanan beberapa kota sudah disinggung pada makalah Setiawan (2013a). Karakteristik inflasi kota-kota di Indonesia tahun 2009-2013 telah dibahas dalam makalah Setiawan (2013b). Dalam makalah ini, akan dibahas tentang perbandingan karakteristik inflasi kota-kota yang menjadi perhatian yaitu kota-kota di Indonesia bagian Timur yang sudah digunakan dalam perhitungan inflasi di Indonesia sejak tahun 1979 yaitu kota Manado, Ambon, Makasar, Jayapura, Denpasar, Mataram dan Kupang. Berdasarkan SBH (Survei Biaya Hidup) 2007, Bali dan Nusa Tenggaran mempunyai bobot inflasi total sebesar $3 \%$ sedangkan Kalimantan, Sulawesi, Ambon dan Papua mempunyai bobot inflasi sebesar 13,8 \% dalam perhitungan inflasi nasiona1/Indonesia (Web 1). Namun demikian kota-kota di Kalimantan, tidak menjadi perhatian dalam maka lah ini. Perlu diketahui bahwa inflasi sesudah Juli 2008, perhitungan inflasi menggunakan 66 kota berdasarkan SBH 2007 dalam perhitungan inflasi Indonesia dibandingkan sebelumnya yang hanya menggunakan 45 kota dan berdasarkan SBH 2002. SBH 2012 mulai akan digunakan pada perhitungan inflasi bulan Februari 2014 yang menggunakan 82 kota yang terdiri dari 66 kota yang telah digunakan dalam perhitungan inflasi sebelumnya dan 16 kota tambahan yang terdiri dari 
Meulaboh, Bukittinggi, Tembilahan, Bungo, Lubuk Linggau, Metro, Tanjung Pandan, Cilacap, Kudus, Banyuwangi, Singaraja, Tanjung, Bulukumba, Baubau,Tual, dan Merauke (BRS BPS, 2014).

\section{Dasar Teori}

Statistik deskriptif yang berkaitan dengan statistik rata-rata, median, skewness, excess kurtosis, koefis ien variasi dan koefisien korelasi Pearson telah banyak dibahas dan digunakan untuk meringkas data. Statistik tersebut juga akan digunakan untuk mendeskripsikan karakteristik inflasi kota-kota yang menjadi perhatian dalam penulisan makalah ini. Rata-rata, median, skewness, excess kurtosis, koefis ien variasi dapat menggunakan definisi seperti yang digunakan dalam Harinaldi (2005). Tetapi MS Excel juga menggunakan definisi lain yang digunakan untuk skewness yaitu :

$$
\frac{n \sum_{i=1}^{n}\left(\frac{X_{i}-\bar{X}}{s}\right)^{3}}{(n-1)(n-2)}
$$

dengan $\bar{X}$ dan $s$ masing-masing adalah rata-rata dan simpangan baku sampel. Untuk excess kurtosis menggunakan definisi sebagai berikut :

$$
\frac{n(n-1) \sum_{i=1}^{n}\left(\frac{X_{i}-\bar{X}}{s}\right)^{4}}{(n-1)(n-2)(n-3)}-\frac{3(n-1)^{2}}{(n-2)(n-3)} .
$$

Untuk membandingkan statistik sebelum dan sesudah krisis moneter 1998 digunakan statistik Wilcoxon yang tidak mensyaratkan distribusi normal dari data. Informasi lebih lanjut dari statistik Wilcoxon dapat dilihat pada Martono (2010).

\section{Metode Penelitian}

Data yang digunakan adalah data inflasi bulanan untuk bulan Januari 1979 sampai dengan Desember 2013 yang diperoleh pada website resmi Badan Pusat Statistik (BPS) untuk kota-kota di Indonesia bagian Timur yaitu kota-kota yang termasuk dalam 17 kota yang digunakan dalam perhitungan inflasi bulanan mulai tahun 1979. Kota-kota yang la in tidak diperhatikan karena belum digunakan dalam perhitungan inflasi bulanan mulai tahun 1979. Data inflasi bulanan dan data inflasi tahunan dilakukan analisis statistik deskriptif dan analisis statistik Wilcoxon.

\section{Hasil dan Pembahasan}

Berdasarkan data tersebut diperoleh grafik garis dari inflasi tahunan dari tahun 1979 sampai dengan tahun 1997 pada Gambar 1 dan dari tahun 1999 sampai dengan tahun 2013 pada Gambar 2. Terlihat bahwa pola inflasi tahunan sesudah krisis moneter hampir sama untuk kota-kota di Indonesia bagian Timur sedangkan pola inflasi tahunan sebelum tahun 1990 untuk kota Ambon cenderung berbeda dengan yang lain. Hal itu juga didukung oleh koefisien korelasi antara kota Ambon dengan kota-kota la in kurang dari batas signifikansi 0,458 untuk ukuran sampel $n=19$ sedangkan koefisien korelasi antar kota-kota yang lain signifikan. Hal itu berarti, kecuali untuk kota Ambon, inflasi tahunan kota yang satu terkait dengan inflasi tahunan kota yang lain.

Inflasi tahunan Indonesia bagian Timur sebelum krisis moneter mempunyai rata-rata 9,27 \% per tahun sedangkan sesudah krisis moneter mempunyai rata-rata 7,73\% per tahun. Koefis ien variasi inflasi tahunan terendah sebelum kris is moneter dicapai Denpasar $(0,39)$ dan tertinggi dicapai Ambon $(0,64)$. Hal itu berarti inflasi tahunan di Denpasar cenderung stabil tinggi yaitu dengan rata-rata inflasi tahunan $10,45 \%$ per tahun lebih tinggi dari rata-rata inflasi tahunan Indonesia bagian Timur yaitu sebesar 9,27 \% per tahun sedangkan di Ambon cenderung berfluktuasi. Sesudah krisis moneter, koefis ien variasi terendah dicapai oleh Kupang $(0,30)$ dan tertinggi di Manado $(0,61)$. Hal itu berarti, inflasi tahunan Kupang cenderung stabil tinggi yaitu sebesar 8,77 \% per tahun sehingga lebih tinggi dari rata-rata inflasi tahunan di Indonesia bagian Timur yaitu sebesar 7,73 \% per tahun.

Dengan menggunakan uji statistik Wilcoxon untuk menguji apakah rata-rata inflasi tahunan kota-kota di Indonesia bagian Timur sebelum dan sesudah kris is moneter berbeda secara signifikan 
maka dapat diperoleh nilai- $p$ mendekati 0,028 sehingga rata-rata inflasi tahunan kota-kota di Indonesia bagian Timur berbeda secara signifikan yaitu mengalami penurunan. Dengan cara yang sama hal itu juga bisa dilakukan untuk koefisien variasi dan skewness sehingga berturut-turut diperoleh nilai- $p$ sebesar 0,352 dan 0,203 artinya berturut-turut tidak ada perbedaan koefisien variasi dan skewness kota-kota di Indonesia bagian Timur sebelum dan sesudah krisis moneter. Untuk excess kurtosis diperoleh kesimpulan bahwa terdapat perbedaan sebelum dan sesudah krisis moneter yaitu distribusi inflasi tahunan menjadi lebih datar (flat).

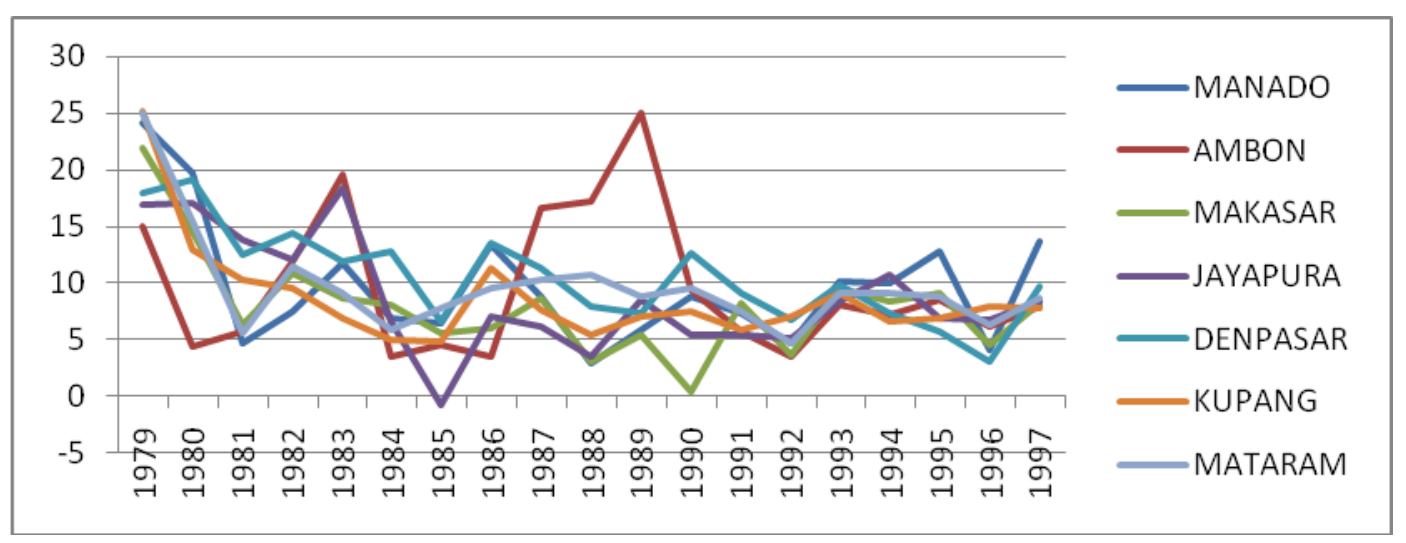

Gambar 1. Grafik garis inflasi tahunan dari tahun 1979 sampai dengan tahun 1997.

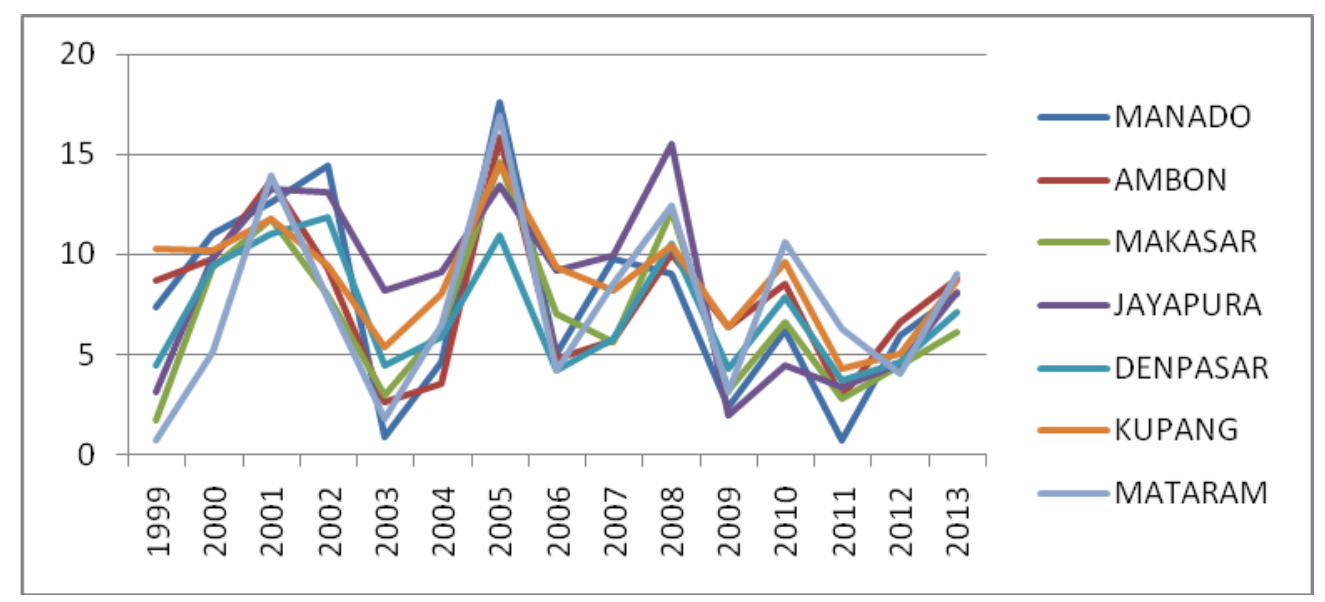

Gambar 2. Grafik garis inflasi tahunan dari tahun 1999 sampai dengan tahun 2013.

Berdasarkan data inflasi bulanan tersebut diperoleh grafik perbandingan rata-rata, simpangan baku koefisien variasi bulanan sebelum dan sesudah krisis moneter pada Gambar 3. Terlihat bahwa rata-rata inflasi bulanan sebelum krisis moneter lebih tinggi dari rata-rata inflasi bulanan sesudah krisis moneter. Hal itu juga didukung oleh uji statistik Wilcoxon yang mempunyai nilai- $p$ sebesar 0,028 sehingga terdapat perbedaan signifikan dan rata-rata inflasi bulanan sesudah krisis moneter lebih rendah dari rata-rata inflasi bulanan sebelum $\mathrm{kr}$ is is moneter. Pada sisi lain, koefisien korelasi antara rata-rata inflasi sebelum dan rata-rata sesudah kris is moneter tidak signif ikan sehingga rata-rata inflasi bulanan yang tinggi pada kota sebelum krisis moneter tidak selalu mempunyai rata-rata inflasi yang tinggi setelah krisis moneter. Apabila uji yang sama dilakukan untuk simpangan baku dan koefisien variasi maka berurut-turut diperoleh nilai- $p$ sebesar 0,173 dan 0,237 sehingga tidak ada perbedaan signifikan pada kedua statistik tersebut pada waktu sebelum dan sesudah krisis moneter. Hal itu berarti, apabila dilihat dari koefisien variasi tidak ada perubahan kestabilan inflasi bulanan untuk kota-kota di Indonesia bagian Timur. Di samping itu koefisien korelasi antara koefisien variasi sebelum dan sesudah krisis moneter sebesar 0,79 dengan nilai- $p$ sebesar 0,036 sehingga kota-kota yang mempunyai koefisien variasi tinggi terkait dengan kota-kota yang mempunyai koef is ien kore lasi yang tinggi dan sebaliknya. 


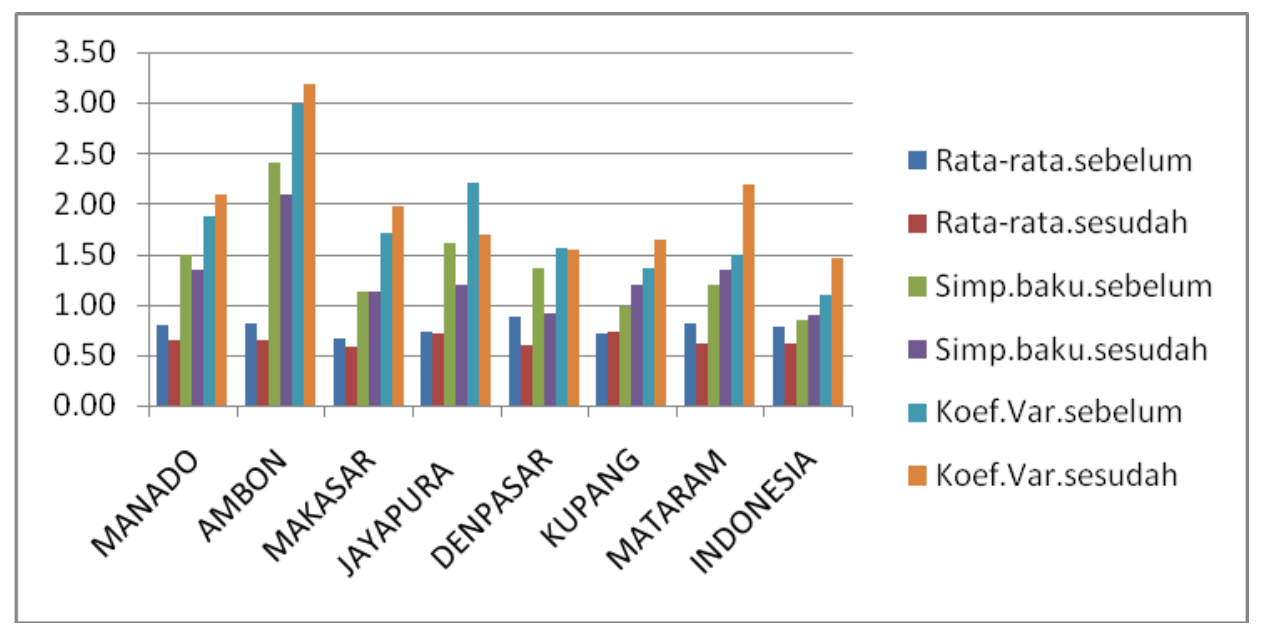

Gambar 3. Perbandingan rata-rata, simpangan baku dan koefisien variasi sebelum dan sesudah krisis moneter.

Tabel 1 menyatakan perbandingan skewness, excess kurtosis dan jangkauan (range) inflasi bulanan sebelum dan sesudah krisis moneter. Terlihat bahwa hanya Makasar yang mempunyai skewness negatif. Skewness terbesar sebelum kris is moneter di kota Kupang yaitu 1,76 sedangkan skewness terbesar di kota Makasar yaitu sebesar 2,89, namun masih lebih kecil dari skewness Indonesia yaitu sebesar 4,52. Skewness positif berarti mempunyai densitas yang menceng ke kanan sehingga cukup banyak yang mempunyai inflasi bulanan lebih tinggi dibandingkan dengan yang lain. Demikian juga excess kurtosis terbesar sebelum kris is moneter dicapai oleh kota Makasar sedangkan excess kurtosis terbesar dicapai oleh kota Mataram yaitu sebesar 17,89 namun masih lebih kecil dari excess kurtosis Indonesia (yaitu 37,79). Kota Ambon mempunyai jangkauan inflasi bulanan yang terbesar untuk sebelum dan sesudah krisis moneter yaitu sebesar 22,99\% pada waktu sebelum krisis moneter dan 15,02 \% pada waktu sesudah krisis moneter. Jangkauan inflasi bulanan yang besar tersebut juga didukung oleh boxplot pada Gambar 4 dan Gambar 5. Terlihat juga banyak inflasi bulanan yang jauh lebih tinggi atau jauh lebih rendah dibandingkan dengan inflasi bulanan di kotakota lain. Gambar 4 dan Gambar 5 berturut-turut memperlihatkan boxplot inflasi bulanan sebelum dan sesudah krisis moneter.

Tabel 1. Tabel perbandingan skewness, excess kurtosis dan jangkauan inflasi bulanan sebelum dan sesudah krisis moneter.

\begin{tabular}{|l|r|r|r|r|r|r|r|r|}
\hline & MANADO & AMBON & MAKASAR & JAYAPURA & DENPASAR & KUPANG & MATARAM & INDONESIA \\
\hline Skewness.sebelum & $\mathbf{1 , 1 8}$ & $\mathbf{0 , 1 8}$ & $\mathbf{- 0 , 2 2}$ & $\mathbf{0 , 1 6}$ & $\mathbf{0 , 6 4}$ & $\mathbf{1 , 7 6}$ & $\mathbf{0 , 7 7}$ & $\mathbf{1 , 6 4}$ \\
\hline Skewness.sesudah & $\mathbf{1 , 4 4}$ & $\mathbf{0 , 4 6}$ & $\mathbf{2 , 8 9}$ & $\mathbf{1 , 3 3}$ & $\mathbf{1 , 9 8}$ & $\mathbf{1 , 6 2}$ & $\mathbf{2 , 6 2}$ & $\mathbf{4 , 5 2}$ \\
\hline Kurtosis.sebelum & $\mathbf{2 , 6 1}$ & $\mathbf{7 , 0 6}$ & $\mathbf{1 1 , 5 8}$ & $\mathbf{5 , 4 7}$ & $\mathbf{1 , 2 0}$ & $\mathbf{4 , 3 0}$ & $\mathbf{1 , 7 3}$ & $\mathbf{3 , 8 5}$ \\
\hline Kurtosis.sesudah & $\mathbf{7 , 0 6}$ & $\mathbf{2 , 5 3}$ & $\mathbf{2 0 , 2 9}$ & $\mathbf{4 , 9 2}$ & $\mathbf{1 1 , 9 3}$ & $\mathbf{6 , 6 0}$ & 17,89 & 37,79 \\
\hline range.sebelum & $\mathbf{9 , 6 3}$ & $\mathbf{2 2 , 9 9}$ & $\mathbf{1 3 , 1 9}$ & $\mathbf{1 5 , 5 3}$ & $\mathbf{8 , 7 7}$ & $\mathbf{6 , 4 3}$ & $\mathbf{7 , 5 1}$ & $\mathbf{5 , 3 1}$ \\
\hline \begin{tabular}{l} 
range.sesudah \\
\hline
\end{tabular} & $\mathbf{1 2 , 0 6}$ & $\mathbf{1 5 , 0 2}$ & $\mathbf{1 1 , 1 8}$ & $\mathbf{9 , 4 2}$ & $\mathbf{8 , 7 4}$ & $\mathbf{9 , 2 6}$ & $\mathbf{1 2 , 9 2}$ & $\mathbf{9 , 7 5}$ \\
\hline
\end{tabular}




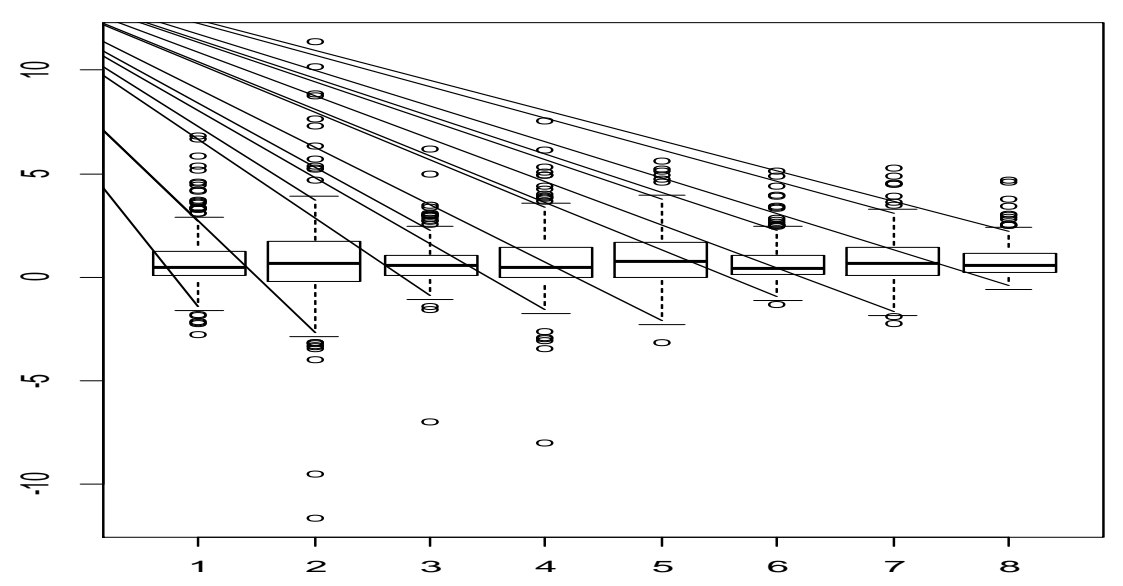

Gambar 4. Boxplot inflasi bulanan sebelum krisis moneter berurut-turut kota Manado, Ambon, Makasar, Jayapura, Denpasar, Kupang, Mataram dan dibandingkan dengan Indonesia.

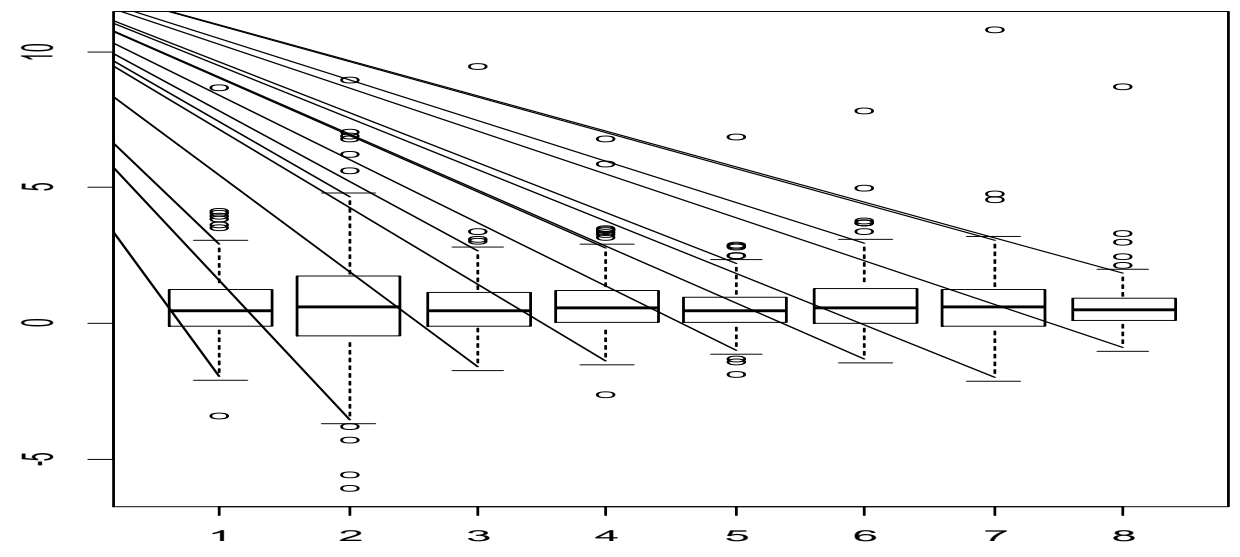

Gambar 5. Boxplot inflasi bulanan sesudah krisis moneter berurut-turut kota Manado, Ambon, Makasar, Jayapura, Denpasar, Kupang, Mataram dan dibandingkan dengan Indonesia.

Grafik densitas dari inflasi bulanan sebelum krisis moneter (yang digambarkan putus-putus) dan sesudah krisis moneter (yang digambarkan dengan garis tanpa putus) diberikan pada Gambar 6. Terlihat bahwa untuk Kupang, Denpasar dan Mataram mengalami perubahan sedangkan untuk kotakota lain dan Indonesia tidak banyak berubah. 

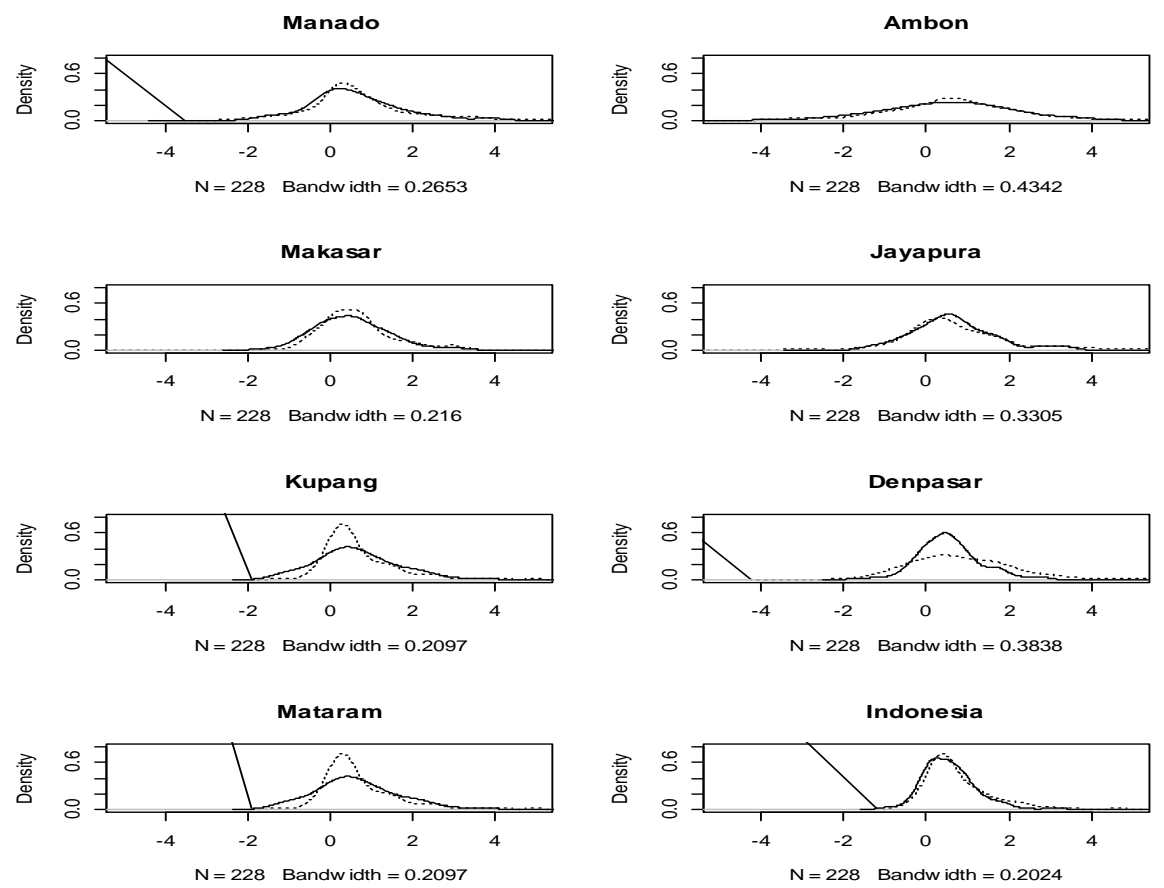

Gambar 6. Grafik densitas dari inflasi bulanan sebelum dan sesudah krisis moneter.

Karakteristik rata-rata inflasi bulanan untuk tiap-tiap bulannya sebelum dan sesudah krisis moneter diberikan pada Gambar 7 dan Gambar 8. Sebelum kris is moneter, terdapat keanehan yaitu bahwa rata-rata inflasi bulan Desember di kota Manado relatif kecil yaitu sebesar 0,16 padahal sebagian besar penduduk kota Manado beragama Kristen sehingga dengan adanya perayaan Natal seharusnya pada saat itu cenderung mempunyai inflasi bulanan tinggi. Namun demikian, pada bulan Januari di kota-kota manapun di Indonesia bagian Timur, inflasi bulanan cenderung tinggi yaitu lebih tinggi dari rata-rata inflasi bulanan di Indonesia bagian Timur yaitu sebesar 0,80\%. Sesudah krisis moneter, inflasi bulanan juga cenderung tinggi untuk bulan Januari yaitu di atas rata-rata inflasi bulanan di Indonesia bagian Timur yaitu sebesar 0,79\% sedangkan untuk bulan Maret, April dan September cenderung rendah. Bulan April sebelum krisis moneter terjadi inflasi yang cukup tinggi bahkan di atas rata-rata, tetapi tidak demikian halnya sesudah krisis moneter.

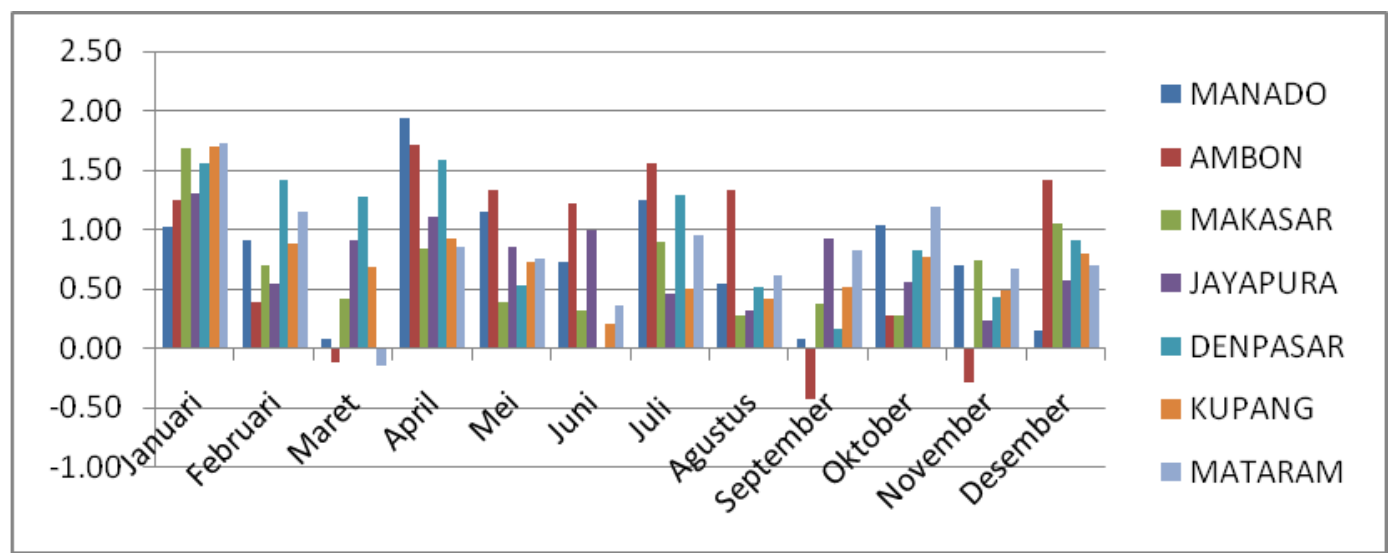

Gambar 7. Rata-rata inflasi bulanan untuk bulan Januari sampai Dese mber sebelum krisis moneter. 


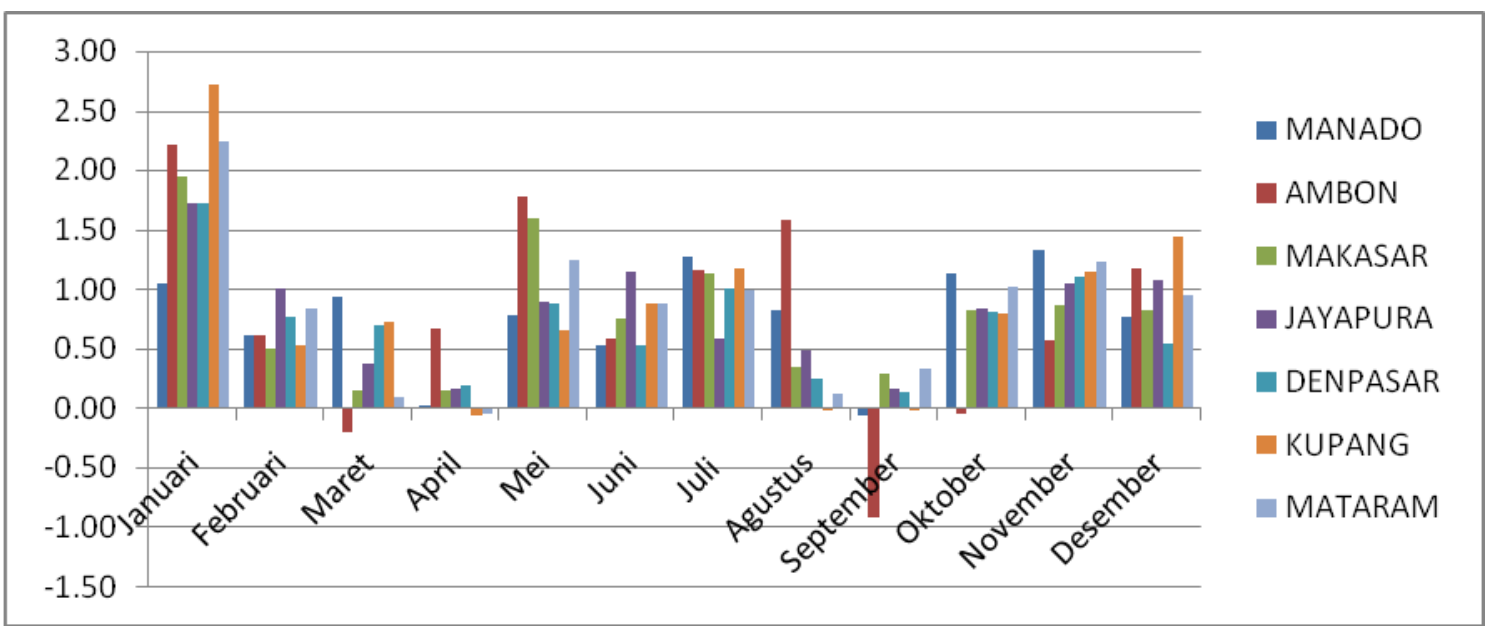

Gambar 8. Rata-rata inflasi bulanan untuk bulan Januari sampai Dese mber sesudah krisis moneter.

Tabel 2. Tabel koefisien korelasi kota-kota di Indonesia bagian Timur dan juga dibandingkan dengan nasional (Indonesia) berdasarkan data inflasi bulanan sebelum krisis moneter.

\begin{tabular}{|l|c|c|c|c|c|c|c|c|}
\hline & MANADO & AMBON & MAKASAR & JAYAPURA & DENPASAR & KUPANG & MATARAM & INDONESIA \\
\hline MANADO & 1 & 0,23 & 0,35 & 0,18 & 0,29 & 0,32 & 0,39 & 0,58 \\
\hline AMB ON & 0,23 & 1 & 0,23 & $-0,01$ & 0,04 & 0,09 & 0,14 & 0,23 \\
\hline MAKASAR & 0,35 & 0,23 & 1 & 0,26 & 0,38 & 0,41 & 0,39 & 0,62 \\
\hline JAYAPURA & 0,18 & $-0,01$ & 0,26 & 1 & 0,2 & 0,41 & 0,24 & 0,35 \\
\hline DEN PASAR & 0,29 & 0,04 & 0,38 & 0,2 & 1 & 0,47 & 0,46 & 0,55 \\
\hline KUPANG & 0,32 & 0,09 & 0,41 & 0,41 & 0,47 & 1 & 0,51 & 0,6 \\
\hline MATARAM & 0,39 & 0,14 & 0,39 & 0,24 & 0,46 & 0,51 & 1 & 0,65 \\
\hline INDONESIA & 0,58 & 0,23 & 0,62 & 0,35 & 0,55 & 0,6 & 0,65 & 1 \\
\hline
\end{tabular}

Tabel 2 memperlihatkan tentang koefisien korelasi antar kota-kota di Indonesia bagian Timur berdasarkan data inflasi bulanan sebelum krisis moneter. Terlihat bahwa kota Ambon tidak berkorelasi secara signifikan terhadap kota Jayapura, Denpasar dan Kupang dengan batas sign ifikansi untuk $n=228$ sebesar 0,13 dan dengan kota-kota yang lain hanya berkorelasi lemah. Hal itu berarti inflasi bulanan di kota Ambon tidak terkait atau hanya berkorelasi lemah dengan inflasi bulanan di kota-kota lain di Indonesia bagian Timur. Sesudah kris is moneter, kota-kota di Indonesia bagian Timur mempunyai koefisien yang signifikan sehingga inflasi bulanan di suatu kota cenderung terkait dengan kota-kota lain.

\section{Kesimpulan}

Dalam makalah ini telah dipresentasikan karakteristik inflasi di kota-kota Indonesia bagian Timur sebelum dan sesudah krisis moneter. Inflasi tahunan untuk kota-kota tersebut cenderung mempunyai pola yang sama setelah krisis moneter namun sebelum krisis moneter kota Ambon mempunyai pola yang cenderung berbeda dengan yang lainnya. Rata-rata inflasi bulanan dan rata-rata inflasi tahunan cenderung turun secara signifikan sesudah krisis moneter dibandingkan setelah krisis moneter.

\section{Daftar Pustaka}

[1] ......., 2014, Berita Resmi Statistik BPS No. 09/01/Tahun XVII, 2 Januari 2014, BPS, Jakarta.

[2] Harinaldi, 2005, Prinsip-prinsip Statistik untuk Teknik dan Sains, Penerbit Erlangga, Jakarta. 
[3] Martono, Nanang. 2010. Statistik Sosial: Teori dan Aplikasi Program SPSS. Edisi Pertama.Yogyakarta: Penerbit Gava Media.

[4] Setiawan, Adi, 2012a, Penentuan Distribusi Skewness dan Kurtosis dengan Metode Resampling berdasar Densitas Kernel (Studi Kasus Pada Analisis Inflasi Bulanan Komoditas bawang Merah, Daging Ayam ras dan Minyak Goreng di Kota Semarang), Prosiding Seminar Nasional Sains dan Pendidikan Sains, Vol 3 No 1.

[5] Setiawan, Adi, 2012b Perbandingan Koef is ien Variasi antara 2 Sampel dengan Metode Bootstrap (Studi Kasus pada Analisis Inflasi Bulanan Komoditas Beras, Cabe Merah dan Bawang Putih di Kota Semarang) Jornal "De Cartesian" Universitas Sam Ratulangi Manado Volume 1 No 1.

[6] Setiawan, Adi, 2013a, Statistika di Era Super Data Set, Prosiding Seminar Nasional Matematika, Sains dan Teknologi Informasi Universitas Sam Ratulangi 14 Juni 2013.

[7] Setiawan, Adi, 2013b, Karakteristik Inflasi Bulanan Kota-kota di Indones ia Tahun 2009-2013, Prosiding Seminar Nasional Matematika dan Pendidikan Matematika UNY Yogyakarta 9 November 2013.

Web 1:

http://www.bi.go.id/id/publikasi/kajian-ekonomiregiona1/jakarta/Documents/341d00793881464a9211251af6828075box3.pdf 